\title{
ST. JEROME IN THE HERITAGE AND TRADITION OF THE OLD CHURCH SLAVONIC LITURGY
}

\author{
Ivan Botica - Kristijan Kuhar
}

DOI: $10.17846 /$ CL.2021.14.1.48-58

\begin{abstract}
BOTICA, Ivan - KUHAR, Kristijan. St. Jerome in the Heritage and Tradition of the Old Church Slavonic Liturgy. The figure of St. Jerome had left traces in the history of Old Church Slavonic Liturgy and places where the Roman Rite in the Old Church Slavonic Language was celebrated. From 13th century St. Jerome became the Patron saint of Croatian Glagolitism due to the developed cult of his sainthood. During the Pontificate of Pope Innocent IV, Glagolitism was enculturated into the Catholic Church in such a manner that it was placed under the patronage of Saint Jerome. This refers to a spiritual culture from Croatian territory, whereby the Roman Rite could be performed in the Church Slavonic language with exclusive use of the Glagolitic script. Through this act, Saint Jerome became the author of the Glagolitic script and protector of the Roman Rite in Church Slavonic. Earliest records of reverence of Saint Jerome have been found on Glagolitic territory, dated to the period even before Glagolitism was enculturated into the Roman Catholic world, in continental Istria in particular, which was considered Saint Jerome's homeland. The worship of Saint Jerome enhanced in the Humanism and Renaissance period, when the Croats started regarding Saint Jerome as their national saint, reflected in Croatia by numerous monasteries, churches, chapels and altars erected in his honour. The worship of Saint Jerome is also evident in numerous Croatian Glagolitic missals and breviaries containing liturgical services honouring Saint Jerome. This paper explores the extent to which Saint Jerome was worshipped in the heritage and tradition of Glagolitic liturgical manuscripts, which are typologically classified as liturgy books »according to the use of the Roman Curia".
\end{abstract}

Keywords: Saint Jerome, Saint Jerome's churches, Glagolitic Breviaries and Missals, Roman Rite in Old Church Slavonic, Glagolitic script, Istria

\section{Introduction}

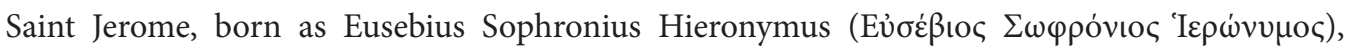
is a saint born at Stridonium, non-localised settlement in late-antiquity Dalmatia bordering Pannonia. He is best known as the redactor of the Bible from Greek and Hebrew into Latin. Jerome's edition of the Bible, the Vulgata, is still an important text of Catholicism. It was used in the medieval Latinity period for developing literacy. Therefore, he is recognised by the Roman Catholic Church as one of the Church Fathers and Doctors of the Church. Naturally, his life and work have constantly been in the focus of scholarly research.

It is less known that Saint Jerome was also the patron saint of Glagolitism (Verkholantsev 2010, 225-63). This refers to the spiritual and cultural phenomenon of the Roman Catholic Church, documented almost solely on Croatian territory, which received the Papal placet for performing the Roman Rite liturgical services in the Church Slavonic language under the condition that the lingua sacra of the Roman Catholic Church is written in Glagolitic script. Pope Innocent IV $(1243$ - 1254) proclaimed Saint Jerome's patronage of authorship of the Glagolitic script and 
Glagolitic liturgy, i.e. the Roman Rite in the Church Slavonic language. ${ }^{1}$ Croatian scholarship and culture label the entirety of this liturgical and ecclesiastical phenomenon »Glagolitism«.

Naturally, the Glagolitic clergy, who celebrated Roman liturgy in Church Slavonic, considered Saint Jerome their originator. This relegated the role of Sts. Cyril and Methodius in the creation of the Glagolitic script and introducing the Church Slavonic language into Roman Catholic liturgy to such an extent that they were fairly unknown until late 19th century (Verkholantsev 2010, 225-63). On the other hand, Saint Jerome became not only the patron of Glagolitism but also the "protector and pride of the Croatian people " (zašćititelj i dika jazika hervaskoga) (Mihaljević 2014,12). Since Early Modern Age, Croats have considered him their national and political symbol, role model to the Croatian Catholic clergy, inspiration to artists, source of local pride, and the search for his place of birth has been underway in many »Illyric « locations (Ivić 2018, 253, 268-269; Špoljarić 2018, 44).

This paper studies the cult of St. Jerome in the Croatian Medieval Glagolitic area by the analysis of Croatian Glagolitic missals and breviaries that contain office in honour of St. Jerome. With this research we hope to encourage the further liturgical and textological research of the euchological and other liturgical elements in the office in honour of St. Jerome. The main research goal is to indicate the area in which the cult of St. Jerome was fully developed, by analysing liturgical documents and by analysing hagiotopography.

Croatian Glagolitic missals and breviaries follow the typology of liturgy books »according to the use of the Roman Curia " (secundum morem Romanae curiae). They were translated into Church Slavonic during the 14th century ${ }^{2}$ while their textual transmission, accompanied by intense Croatisation of grammar and lexis, was underway until the Council of Trent (1545 - 1563). After this, feast days retained their established office (officium) in breviaries and their euchological pattern in missals up until the liturgical reform introduced by the Second Vatican Council, which caused Church Slavonic, as the lingua sacra of Eastern Adriatic dioceses, to mostly disappear from the Roman Rite.

\section{Saint Jerome in the Latin Roman Liturgy}

The worship of Saint Jerome in the Roman Liturgy began in late 8th century, when Saint Jerome's name appeared in the "Communicantes", prayer in the canon of the mass of certain Latin sacramentaries of the Frankish provenance (from Gellone Abbey, Fulda Abbey, etc.) ${ }^{3}$. Even though his name was registered in the canon of the mass of Gregory-Hadrian's Sacramentary (Deshusses 1992, 88), alongside some non-martyrs, its first appearance in the Roman context was in Vetus

1 There are different interpretations of this pontifical rescript (for the recent interpretation see: Kraft Soić 2016a, 2016b). The document has been preserved only in transcript which contains approval of the Slavonic liturgy in the area of Senj diocese formally given to the bishop Filip of Senj: Porrecta nobis tua petitio continebat quod in Sclavonia est littera specialis, quam illius terre clerici se habere a beato Jeronimo asserentes, eam observant in divinis officis celebrandis. [...] Nos, igitur, attendentes quod sermo rei et non est res sermoni subiecta, licentiam tibi in illis dumtaxat partibus ubi de consuetudine observatur premissa [...] (Kraft Soić 2016a); Even the glagolitic letters were called letters of St. Jerome (Štefanić 1976).

2 It is important to mention that Croatian glagolitic liturgical manusripts were written and translated even before the 14th century, but they are not preserved, except in fragments. During the 13th and 14th century, probably under the influence of the placte of Innocent IV, the liturgical books were revised according to the new typology of liturgical books, and biblical readings according to the Vulgate (Corin 1997, 527-538; Reinhart 1990, 45-52).

3 Codices liturgici latini antiquiores, nr. 855 and 970. 
missale Romanum monasticum Lateranense, ${ }^{4}$ dating back to the 11th/12th century. The worship of Saint Jerome in Rome, i.e. in Roman Diocese and Roman Church, came into full swing during the 13th century, following the transfer of the chest containing Saint Jerome's remains from Bethlehem to the Basilica di Santa Maria Maggiore in Rome. His liturgical commemoration has been set to 30 September, which is the day of his death, while the transfer of his remains, or Translatio sancti Hieronymi, is commemorated on 9 May, when the Roman Church commemorated the »transfer" of relics of St Andrew the Apostle, Saint Luke the Evangelist, Saint Paul's disciple Saint Timothy, Saint Jerome the Presbyter and Saint Nicholas Bishop. The collective Martyrologium romanum records the following text next to Saint Jerome's name: Romae item Translatio sancti Hieronymi Presbyteri, confessoris et Ecclesiae Doctoris ex Betlehem Judae ad Basilicam sanctae Mariae ad Praesepe (Martyrologium romanum Gregorii XIII).

The liturgical reference to Saint Jerome had not been recorded in the oldest Roman missal secundum consuetudinem Romanae curiae (redacted by Fr. Haymo of Faversham), and its first record dates back to the first print of the missal secundum consuetudinem Romanae curiae (1474) (Missale romanum Mediolani 1474 (1907), 388). The status of worship and liturgical celebration of Saint Jerome in the Roman Church reflected the treatment of this saint by the Roman Church. Shortly before his death, Pope Pius II (1458 - 1464) introduced the liturgical memorial Translatio sancti Hieronymi into the Roman calendar and sanctoral, but this liturgical memorial was abolished after the Council of Trent. ${ }^{5}$ The worship never reached a higher level in Rome itself because the chest containing Saint Jerome's remains disappeared from the Santa Maria Maggiore Basilica in late 15 th century.

A more intense worship of Saint Jerome in the Catholic Church started after Pope BonifaceVIII (1294 - 1303) issued a decree whereby four Latin Church Fathers, Saint Jerome being one of them, were promoted to the duplex rank and awarded the title Doctors of the Church (doctores ecclesiae). This led to the increase of Saint Jerome's significance in the entire Church. Until then, he had been celebrated as a Presbyter and teacher of the Church, primarily on the territory under Frankish influence. The reference to Saint Jerome was introduced into the Roman Rite via Frankish liturgical reform by the introduction of Saint Jerome's name into the canon of the mass and creation of a unique euchological pattern for the memorial of Saint Jerome. It should be kept in mind that the Vulgate of St. Jerome was also introduced into the Roman Church from the Frankish tradition. The gap spanning several centuries, until the start of his worship in the 13th century, can only be explained by the fact that Saint Jerome was side-lined by Roman martyrs and saints. It was not until the Humanist period that the »forgotten« father and teacher of the Church received his true place in the liturgical memorials of the Catholic Church. However, unlike the slow development of his cult in the »Latin " part of the Catholic Church, its "Glagolitic « part was very active in transferring the cult and liturgical legend of Saint Jerome as the protector of the »Glagolitic« section of the Catholic Church.

\section{Roman liturgical tradition in Church Slavonic: Glagolitic missals and breviaries}

It has already been mentioned that, in terms of typology, Croatian Glagolitic missals and breviaries are to be classified as liturgy books secundum consuetudinem Romanae curiae and that they had

II. Kalendas Octobris. S. Hieronymi presbyteri.

5 In Missale romanum editio princeps (1570) and in Breviarium Romanum editio princeps (1568), but it is mentioned in Martyrologium romanum editio princeps (1584). 
been created in the period from mid-14th to mid-16th century. They were used to codify and consolidate Croatian Church Slavonic as one of the linguae sacra of the Roman Catholic Church. Even though liturgical books written in Old Church Slavonic belong typologically to the Roman Rite, they did not follow texts of the Latin Roman liturgical tradition in every single detail ${ }^{6}$. Rather, they aimed at preserving the distinctiveness of its own tradition of textual transmission from older translations from Latin to Old Church Slavonic language that are preserved in older Glagolitic liturgical books.?

This fact is well reflected in the euchological pattern related to the liturgical memorial of Saint Jerome. Our research encompassed texts from the following Croatian Glagolitic missals: Vatican missal Illirico 4 (216b-216d), Missal of Count Novak (224d-225a), Missal of Hrvoje, Duke of Split (184c), First Ljubljana (Beram) missal (187c-188a), Eighth Vatican missal (184c), First Vrbnik missal (242a), and the Editio princeps of Glagolitic missal (pp. 246-347). All missals referred to above share the same structure, in typological terms, which is identical to the Latin missals »according to the use of the Roman Curia «. However, Vatican missal Illirico 4, dated to early 14th century is the oldest Croatian Glagolitic missal »according to the use of the Roman Curia« and has been used for the longest time. All mentioned missals follow exact euchological pattern, i.e. three prayers: Collecta, Super oblata and Post communionem. There are also differences: the prayer super oblata Dari molim $t e^{8}$ in the said missal (216d) is longer compared to the others, and it is absent in the First Ljubljana (Beram) missal (188a). ${ }^{9}$ Some euchological elements present in Croatian Glagolitic missals show distinctions from the Latin template. For instance, the first euchological element (collecta) was probably translated from an older template and does not match the Roman pattern, leading to an unknown template, probably from some North Italian liturgical manuscript. ${ }^{10}$

\begin{tabular}{|c|c|}
\hline $\begin{array}{l}\text { Church Slavonic collecta } \\
\text { Vatican Missal Illirico } 4\end{array}$ & $\begin{array}{l}\text { Latin collecta } \\
\text { Missale Romanum } 1474\end{array}$ \\
\hline 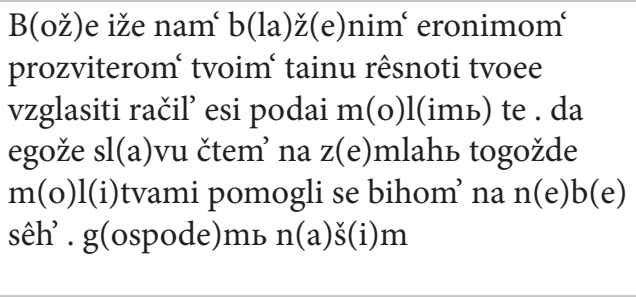 & $\begin{array}{l}\text { Deus qui ecclesie tue in exponendis sacris } \\
\text { scripturis. beatum ieronimum gloriosum } \\
\text { confessorem tuum doctorem maximum } \\
\text { et electum prouidere dignatus es. presta } \\
\text { quesumus. ut eiusdem suffragantibus meritis. } \\
\text { quod ore simul et opere docuit. et adiuuante } \\
\text { exercere ualeamus. }\end{array}$ \\
\hline
\end{tabular}

In other words, Church Slavonic collecta used for liturgical reference to Saint Jerome is not a direct translation of the collecta from the Latin Roman tradition as registered in the missals. In terms of meaning, it is close to the Latin text of the Commune doctorum prayer ${ }^{11}$; however, the collecta from the Church Slavonic Commune doctorum had been adjusted to the theological expression

6 It is visible in the transcription of the older euchological elements in various later liturgical books, especially in the liturgical services of the saint patrons of the churches where the liturgical books were used (Pantelić 1971).

7 For more, see Kuhar 2017.

8 Dari m(o)l(imb) te g(ospod)i vzdanie s(ve)ti i hodataûĉu b(la)ž(e)nomu eronimu isp(o)v(ê)dniku tvoemu nasb simi ot grêhь n(a)ših' skvr'n' očisti (Vatican Missal Illirico 4, f. 216d).

9 The writer did not follow the euchological pattern.

10 The oldest Croatian Glagolitic Liturgical texts match the Latin liturgical texts from Northern Italian area. See more Kuhar 2017. For the development of Croatian Glagolitic Missal, see Corin 1997.

11 Deus, qui populo tuo aeterne salutis beatum N. ministrum tribuisti: praesta, qaesumuns; ut, quem Doctorm vitae habuimus in terris, intercessorem habere mereamus in caelis. Per Dominum. Litrugia tridentina, 433. 
of Church Slavonic. This is especially evident in the expression of the petition in the prayer $d a$ koga slavu čtems no zemli togoje molitvami pomogli se bihoms n' nebesihs (quem Doctorem vitae habuimus in terris, intercessorem habere mereamur in caelis), which is an example of adjusted translation. Therefore, the question arises about the Latin model of these sections of the liturgical text related to the liturgical memorial of Saint Jerome as it is clear that they were not adopted from the Latin missal »according to the use of the Roman Curia «. They must derive from an older liturgical codex, most likely from the Northern Italian area, which was in direct contact with the Glagolitic territory.

Liturgical reference to Saint Jerome can be found in 15 Croatian Glagolitic breviaries (half of the total number of preserved breviaries). In typological terms, they are identical to the Latin breviaries secundum morem Romanae curiae. The difference in the Liturgy of the Hours for liturgical commemoration of Saint Jerome refers to the content of the Liturgy, i.e. its liturgical rank. Breviaries from continental Istria are especially prominent when it comes to the scope of the liturgy service of Saint Jerome, i.e. the liturgical rank of his memorial. The celebration of Saint Jerome was particularly vivid on that territory as it is the area which is often referred to as one of the potential places of Saint Jerome's birth or, to paraphrase the title of a historiographic study by Fr. Josip Bedeković (1752), natale solum magni ecclesiae doctoris sancti Hieronymi. Hence, the most complete Liturgy of the Hours commemorating Saint Jerome can be found in BrHum, BrLab ${ }_{1}$ and $\mathrm{BrN}_{1}$. The latter was created by compiling an unknown source, most probably originating in Istria. The service of Saint Jerome in all other Croatian Glagolitic breviaries is identical to the related service in the Latin breviary secundum morem Romanae curiae.

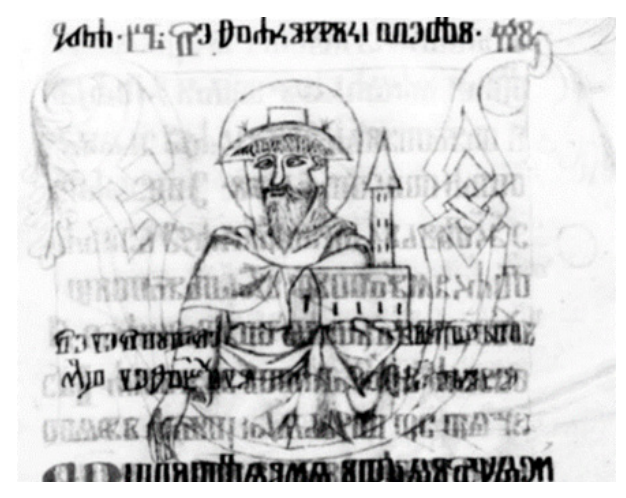

Figure 1. Illumination of Saint Jerome found in Hum breviary

When analysing the textual content of the service of Saint Jerome in Croatian Glagolitic breviaries, we only took into account those that contained a hymn, five readings from the nocturnes, oratio, antiphon for Magnificat, invitatorium, laudes, prima and the Vesper. Only BrHum (144d-147b) contains all these parts. Its Liturgy of the Hours is by far the most elaborate. It is the only breviary containing annotated psalms, Lesser Hours and an illumination of Saint Jerome (see Figure 1). Saint Jerome is the patron saint of Hum, the town that belonged to the Diocese of Trieste, just like Zrenj, and was for a long time under the secular jurisdiction of the Patriarchate of Aquileia (Škunca 2014, 84). The said breviary belonged to the parish church in Hum. The saint is depicted wearing cardinal's garments and a hat, which is the iconography frequently used for depicting Church teachers. In his left hand, we can see him holding a silhouette of what we presume is Basilica di Santa Maria Assunta in Aquileia. $\mathrm{BrN}_{1}$ is the only breviary that can compete with BrHum in terms of the number of liturgical elements. The liturgical services of Saint Jerome in 
all other breviaries are identical in terms of scope: five readings from the nocturnes and oratio. It should be emphasised that as many as 11 Croatian Glagolitic breviaries contain the hymn to Saint Jerome, which is not present in the Latin breviaries secundum morem Romanae curiae. ${ }^{12}$ On the other hand, the collect prayer (oratio) in the breviary is completely identical with the one found in the missals.

We can conclude that the worship of Saint Jerome according to Church Slavonic liturgy books "according to the use of the Roman Curia « mostly corresponded to the Latin Roman templates. The euchological pattern for liturgical commemoration of Saint Jerome in Croatian Glagolitic missals is always accompanied by three euchological elements (prayers). They follow the Latin Roman matrix in all elements apart from the collecta, which the Church Slavonic Roman liturgical tradition, unlike the Latin Roman liturgical tradition, inherited, as a rule, from commune doctorum.

A similar pattern is evident in Croatian Glagolitic breviaries. Of fifteen Croatian Glagolitic breviaries that contain the service of Saint Jerome, only three contained the full service, as is appropriate for a duplex-ranked celebration; one of them only contained readings from the Second and Third Nocturn, while eleven contained the hymn and collect prayer (oratio) alongside the readings. The hymn to Saint Jerome was not registered in the Liturgy of the Hours of the Latin Roman liturgical tradition until the 15th century. Hence it can be considered «added value« to the living worship of Saint Jerome in Glagolitic churches, which could not co-exist with Roman Catholic Churches without Saint Jerome.

\section{Saint Jerome on Glagolitic territory}

The worship of Saint Jerome in Rome dates back to the 13th century. The only earlier cult registered to date was present on Croatian territory. Namely, some Croatian churches consecrated to Saint Jerome can be dated earlier than the 13th century (Hum, Korlat, Lubenice, Sveti Lovreč Labinski, Vižinada) (Badurina 2006). The worship of Saint Jerome spread through the liturgical books from Francia to Rome and Aquileia, i.e. from the north toward the south. Jerome's assumed homeland affiliation (Istria) influenced the fact that the worship of Saint Jerome first became entrenched in the area under the jurisdiction of the Patriarchate of Aquileia. This is evident in the oldest churches consecrated to Saint Jerome that were erected on the territory under the jurisdiction of the Patriarchate of Aquileia (Istria and Kvarner). A prominent role in the spread of the worship of Saint Jerome was held by Pope Pius II, who, as was mentioned before, promulgated the liturgical memorial Translatio s. Hieroniymi to the entire Catholic Church. Prior to being elected Pope, he was the Bishop of Trieste (1447 - 1458), which means that he witnessed in person the reverence of Saint Jerome in his diocese. The Diocese of Trieste and its neighbouring Poreč Diocese, both under the management of the Patriarchate of Aquileia, boasted with the largest number of erected churches, chapels and altars consecrated to Saint Jerome in the entire Catholic Church. In mid-13th century, Thomas the Archdeacon wrote that Saint Jerome's place of birth is located »inland from the Gulf of Kvarner " (Istria) (Arhiđakon 2003, 2-3). The Catholic world of the period believed that Zrenj was the exact place where Saint Jerome had been born (Kelly 1998, 7). The Italian variants of this locality bordering Venetian Istria in the Trieste Diocese are Stregna and Stridone (Grah 2017, 28). Nevertheless, the intention of Pius II, former Bishop of Trieste, to promote the worship of Saint Jerome within the Catholic Church by introducing the Translatio sancti Hieronymi feast day failed to gain ground as the liturgical memorial of the transfer of Saint Jerome's relics was omitted

12 Incipit of the Hymn: b(ož)e iže esi s(vê)tlostb $k r(a) \operatorname{sna} v \hat{e} n(a) c b s(v e) t i h b$ (f. 144d). 
from later missals. He appears in Croatian Glagolitic breviaries as the sanctorem, especially those originating from Istria. The First Ljubljana (Beram) Breviary from late 14th century is, based on our research, the only one that contains the entire Liturgy of the Hours connected with this feast (48b-50b).

Croatia was, without a doubt, the country where Saint Jerome was worshipped the most in the entire Catholic Church (see more Bratulić 2018, 230). This thesis, present in Croatian historiography for more than five centuries, could easily be statistically verified in the total number of churches, chapels and altars consecrated (dedicated) to Saint Jerome. Several monastic orders in Croatia are under patronage of Saint Jerome ${ }^{13}$. Numerous churches consecrated to Saint Jerome bear testimony to the continuous and living reverence of Saint Jerome in Croatia. Below we provide the list of these churches, ordered by the year of their erection or consecration (Badurina 2006):

\begin{tabular}{|c|c|}
\hline 12th c. & $\begin{array}{l}\text { below Helm (Lubenice), Vižinada, old parish church (Hum), cemetery } \\
\text { (Hum); }\end{array}$ \\
\hline 12 th -13 th $c$. & Staniševići (Sveti Lovreč Labinski), Korlat; \\
\hline 13th c. & Kavran, Muntić; \\
\hline 13th -14 th $\mathrm{c}$. & cemetery (Nova Vas Novigradska); \\
\hline 14th c. & Vlašići, Rijeka, Zrenj, Rumenja vrata (Senj), Štrigova, Slano; \\
\hline 15 th c. & $\begin{array}{l}\text { near St. Anna (Krk), Ugljan, Marjan (Split), Vrulja (Kolan), Martinšćica, } \\
\text { u Polju (Ston), Široke (Primošten), Prirov (Vis), Blato na Korčuli, Glavica } \\
\text { (Šipan), Ražanac, Rt (Kali); }\end{array}$ \\
\hline 16th c. & $\begin{array}{l}\text { Gornje Selo (Risika), Mali Kraj (Stara Baška), on the bay (Stari Grad), } \\
\text { cemetery (Skradin), Peroj (Fažana), Pučišća, Zaton Dubrovački, Trsteno, } \\
\text { Dubrovnik; }\end{array}$ \\
\hline 17th c. & $\begin{array}{l}\text { Kobaš (Ston), Grobnik, Bribir (Vinodol), Lopud, Pintor (Milna na Braču), } \\
\text { Miševac (Trogir), Lukoran, Postrana (Žrnovo), fotress (Knin); }\end{array}$ \\
\hline 18th c. & $\begin{array}{l}\text { Lišane, cemetery (Trilj), Gljev (Gala-Gljev), Brštanovo, Veliko Brdo, old } \\
\text { church (Kaštel Gomilica), Valica (Savudrija), Klana; }\end{array}$ \\
\hline 19th c. & Donje Selo (Risika) Jasenice; \\
\hline 20th c. & $\begin{array}{l}\text { Lun, new church (Kaštel Gomilica), Maksimir (Zagreb), Meterize (Šibenik), } \\
\text { Biokovsko Selo (Župa Biokovska). }\end{array}$ \\
\hline
\end{tabular}

Chart 1. 'Glagolitic' and 'Latin' churches consecrated to Saint Jerome in Croatia

The worship of Saint Jerome has become well rooted in Croatia since the Croats have considered him their most educated and most representative saint ever since the Middle Ages (Prosperov Novak 2019). The rootedness of his worship is not conditioned solely by his (non)-localised place of birth, Dalmatiae quondam Pannoniaeque confinium fuit (Stilting and Johannes 1748, 425), but also by the rescript issued by Pope Innocent IV granting the use of Glagolitism in the Catholic Church $^{14}$. As Saint Jerome became the patron saint of Glagolitism, the oldest churches consecrated to him can be found on Glagolitic territory. He certainly became the Glagolitic saint par excellence (Chart 1).

After being canonised as the author of the Glagolitic script and the patron saint of Glagolitism, his cult first became rooted in Roman Catholic churches in which liturgy was read from Croatian

13 Namely, three Franciscan provinces of three Franciscan orders: Franciscan minor friars Province in Zadar, Franciscan Conventual Province in Zagreb and Third Order Regular Province in Zagreb.

14 Kraft Soić 2016a, 2016b. 
Glagolitic missals and breviaries. It was not until later, when Humanism and Renaissance made him the national saint in Croatia, that his cult entered the Latin churches as well (Chart 1).

The earliest worship of Saint Jerome was documented in the North Adriatic area (Istria and Kvarner) under the jurisdiction of the Patriarchate of Aquileia. Aquileia is also the place of origin of the earliest Latin sources used for translating the oldest euchological patterns into Church Slavonic ${ }^{15}$. Hence it is possible that the Church Slavonic euchological pattern in the liturgical memorial of Saint Jerome, which is partially different from the Latin euchological pattern from the missals secundum consuetudinem Romanae curiae, emerged directly due to the mediation of Aquileia, or parts of Northern Italy, which served as a stronger connection for early Glagolitism until mid-13th century than Rome did.

\section{Conclusion}

According to the analysis of the liturgical sources, we can conclude that the worship of Saint Jerome had been deeply rooted on Croatian territory already in the Middle Ages. Long before Roman Pontiff proclaimed Saint Jerome the Doctor of the Church, it was known that he was born on the border between ancient Pannonia and ancient Dalmatia. Thomas the Archdeacon, one of the first chroniclers of Croatia, at the beginning of his work Historia Salonitana (1266) defined Dalmatia by stating that it was "the homeland of the Blessed Jerome, exquisite teacher " hec fuit patria tellus beati Hieronymi, egregii doctoris). In other words, his first association to a person from Dalmatia was Saint Jerome. The proof of living worship of Saint Jerome on present Croatian territory is most evident in numerous monasteries, churches, and chapels built in his honour. Early traces of worship in locations of Church Slavonic liturgy in the Patriarchate of Aquileia, especially in continental Istria, even earlier than in Rome itself, reflect the belief regarding Jerome's origin from the said territory and the desire to protect Glagolitism by using his authority, which the Church, until the Pontificate of Pope Innocent IV, officially brought into question under the heretic title "Methodius's doctrine« (Katičić 1986, 11-44; Klaić 1986, 17-39; Verkholantsev 2010, 247-250; Gračanin and Petrak 2017, 28-42).

All of this changed in mid-13th century when the Pope allowed for the Roman Rite to be performed in the Catholic Church in Church Slavonic. He placed priests and Glagolitic monks, who obtained spiritual strength from the practice called Glagolitism, under the protection of Saint Jerome, who was an unrivalled Church authority. That was the reason why Glagolitism as the liturgical manifestation of the Roman Rite in the Church Slavonic language could exist and last in the Catholic Church in the first place. That was the reason why the sense of belonging to Saint Jerome became deeply rooted, as manifested in numerous churches built in his honour as well as the elaborated liturgical worship of Saint Jerome in Croatian Glagolitic missals and breviaries.

The present paper explored and highlighted the rootedness and scale of worship of Saint Jerome on Glagolitic territory, which was first under the influence of Aquilian, later succeeded by Roman liturgical tradition and jurisdiction. The twenty-eight churches consecrated to Saint Jerome in the Middle Ages bear witness to his well-developed cult. Church Slavonic liturgical texts honouring Saint Jerome are no less frequent. The euchological pattern used for commemoration of Saint Jerome was discovered in five Croatian Glagolitic missals, while the Liturgy of the Hours (officium Divinum) was discovered in as many as fifteen Croatian Glagolitic breviaries. The structure of these liturgical texts is slightly different when compared to the liturgy books they were translated from, i.e. liturgy books "according to the use of the Roman Curia» (secundum morem Romanae

15 See more Kuhar 2017. 
curiae). This means that the Church Slavonic Roman liturgical tradition contained individual elements which were different from the Latin tradition, which was the role model for everything ever since the Papal placet issued in the 13th century.

The abundance of the Liturgy of the Hours honouring Saint Jerome and the extent of his liturgical reference in Croatian Glagolitic breviaries, especially in those within the areal of the Patriarchate of Aquileia, further enhance the presumption that Saint Jerome was most revered in his supposed homeland. That is where the oldest churches of the Catholic Church consecrated to Saint Jerome are located. By the time he started to be revered as a saint, his patria was already largely Glagolitic by script and language. That is why his homeland awarded him with the highest honour by proclaiming him the author of the Glagolitic script and placing Glagolitism, its sublime spiritual value, under his authority.

\section{REFERENCES}

\section{Primary sources}

Baromićs breviary (BrBar). sign. RI-16-1. Zagreb: National and University Library, 429d-430d. Brozićs breviary (BrBroz). sign. RIIA-16-9. Zagreb: National and University Library, 421d-3422d. Codices liturgici latini antiquiores. Gamber, Klaus. 1968. Codices liturgici latini antiquiores. Universitätsverlag Freiburg.

Editio princeps of Glagolitic missal (P). Misal po zakonu rimskoga dvora 1483. 346-347, Zagreb. Eighth Vatican missal (BrVat ${ }_{8}$ ), sign. Borg. Illirico 8. Vatican City: Vatican Apostolic Library, 184c. First Ljubljana (Beram) breviary $\left(\right.$ BrLab $\left._{1}\right)$. sign. Ms 161. Ljubljana: National and University Library, 138c-141a.

First Ljubljana (Beram) missal (MLab ${ }_{1}$ ). sign. Ms 162. Ljubljana: National and University Library, 138c-141a.

First Novi breviary $\left(\mathrm{BrN}_{1}\right)$. Novi Vinodolski: Parish office Novi Vinodolski, 428b-430a.

First Vrbnik missal (MVrb $)$. Vrbnik: Parish office Vrbnik, 242a.

Fourth Vrbnik breviary (BrVrb ${ }_{4}$. Vrbnik: Parish office Vrbnik, 64b-65d.

Hum breviary (BrHum). sign. R 4067. Zagreb: National and University Library, 144d-147d.

Liturgia tridentina. Liturgia tridentina. Fontes - Indices - Concordantia 1568 - 1962, a cura di Mnalio Sodi - Alessandro Toniolo - Placide Bruylants. Librera Editrice Vaticana 2010.

Martyrologium romanum Gregorii XIII. jussu editum Urbani VIII et Clementis X auctoritate recognitum ac deinde anno MDCCXLIX Benedicti XIV labore et studio auctum et castigatum.

Mavro's breviary (BrMav). sign. R 7822. Zagreb: National and University Library, 293d-294c.

Missal of Count Novak (MNov), sign. Cod. slav. 8. Vienna: Austrian National Library, 224d-225a. Missal of Hrvoje, Duke of Split (MHrv). 1973. Missale Hervoiae ducis spalatensis croaticoglagoliticum. Biserka Grabar - Anica Nazor - Marija Pantelić - Vjekoslav Štefanić (eds.). Zagreb - Ljubljana - Graz, 184c.

Missale romanum Mediolani. 1474 (1907). Robert Lippe, John Wickham Legg, and Henry Austin Wilson, ed. London.

Moscow breviary (BrMosk). sign. F. 270, 51/1481. Moskow: The Russian State Library. Rumyantsev Museums, 213b-214b.

Nineteenth Vatican breviary $\left(\right.$ BrVat $\left._{19}\right)$. sign. Vat. Slav. 19. Vatican City: Vatican Apostolic Library, 357b-357d. 
Pašman breviary (BrPm). sign. III b 10. Zagreb: Archive of the Croatian Academi of Sciences and Arts, 270c-271b.

Second Ljubljana (Beram) breviary $\left(\mathrm{BrLab}_{2}\right)$. sign. MS 163. Ljubljana: National and University Library, 150b-151a.

Second Novi breviary $\left(\mathrm{BrN}_{2}\right)$, Novi Vinodolski: Parish office Novi Vinodolski, 488a-489a.

Sixth Vatican breviary (BrVat ${ }_{6}$, sign. Borg. Illirico 6. Vatican City: Vatican Apostolic Library, 179d-181c.

Tenth Vatican breviary $\left(\right.$ BrVat $\left._{10}\right)$, sign. Borg. Illirico 10. Vatican City: Vatican Apostolic Library, 181c-182b.

Vatican missal Illirico 4 (MVat ${ }_{4}$ ), sign. Borg. Ilirico 4. Vatican City: Vatican Apostolic Library, 216b-216d.

\section{Secondary sources}

Badurina, Andelko. 2006. Hagiotopografija Hrvatske. CD-ROM. Zagreb.

Bratulić, Josip. 2018. Svetost i čovječnost (rasprave o hrvatskoj hagiografiji). Split.

Corin, Andrew Roy. 1997. O reformama hrvatskoglagoljskih liturgijskih kjniga u 13. stoljeću. In Damjanović, Stjepan et al. Prvi hrvatski slavistički kongres, Zbornik radova I. Zagreb, 527-238

Damjanović, Stjepan. 1996. „Glagoljica«. In Vujić, Antun (ed). Hrvatski leksikon. vol. 1 (A - K). Zagreb.

Deshusses, Jean. 1992. Le sacramentarire grégorien: ses principales formes d’après les plus anciens manuscrits, Tome premier: Le sacramentaire, le supplément d'Aniane. Fribourg.

Gračanin, Hrvoje - Petrak, Marko. 2017. The notion of the Methodii doctrina in the context of the church synod of Split (AD 925). In Panov, Mitko B. (ed.). Vizantiskata misionerska dejnost i evropskoto nasledstvo. Skopje, 28-42.

Grah, Ivan, Valter Baldaš, Marijan Bartolić, Sergije Jelenić, and Branka Poropat. 2017. Crkva u Istri. Osobe, mjesta i drugi podatci Porečke i Pulske biskupije. Poreč and Pazin: Biskupija Porečka i Pulska and »Josip Turčinović« d.o.o. Pazin.

Ivić, Ines. 2018. The »Making « of a National Saint: Reflections on the Formation of the Cult of Saint Jerome in the Eastern Adriatic. In Supplementi 7, 247-78.

Katičić, Radoslav. 1986. Methodii doctrina. In Slovo 36, 11-44.

Kelly, J. N. D. 1998. Jerome. His Life, Writings, and Controversies. London.

Klaić, Nada. 1986. Kako i kada postaje "Metodijeva doktrina« kulturno dobro Hrvata. Croatica Christiana periodica 10: 17-39.

Kraft Soić, Vanda. 2016a. Otpis Inocenta IV. senjskom biskupa (1248.) pod patronatom sv. Jeronima I. Senjski privilegij iz godine 1248. In Croatia Christiana periodica 77, 1-23.

Kraft Soić, Vanda. 20162. Otpis Inocenta IV. senjskom biskupa (1248.) pod patronatom sv. Jeronima II. Povijesni usud glagoljice i začetci jeronimske tradicije. In Croatia Christiana periodica 78, 17-37.

Kuhar, Kristijan. 2017. Povijesno liturgijske posebnosti euholoških obrazaca ranog razdoblja slavenske liturgije (10. - 14.st.) s osvrtom na predslovlja. Dissertation. University of Zagreb. Zagreb.

Mihaljević Milan. 2014. Uvod. In: Milan Mihaljević, ed. Hrvatski crkvenoslavenski jezik., 9-22. Zagreb.

Pantelić, Marija. 1971. Odraz sredine u hrvatskoglagoljskim liturgijskim kodeksima 14. i 15. stoljeća. In Slovo 21, 324-332. 
Prosperov Novak, Slobodan. 2019. Sveti Jeronim Dalmatinac: zaštitnik Dalmacije. Split.

Reinhart, Johannes. 1990. Najstarije svjedočanstvo za utjecaj Vulgate na hrvatskoglagoljsku bibliju. In Slovo 39-40, 45-52.

Špoljarić, Luka. 2018. Venecijanski Skjavoni i povijesno-liturgijska knjižica u čast sv. Jeronima Ilira iz 1498. godine. In Colloquia Maruliana 27, 43-74.

Štefanić, Vjekoslav. 1976. Nazivi glagoljskog pisma. In Slovo 25-26, 17-76.

S. [Stilting], J. [Johannes]. 1748. De S. Hieronymo presbytero et doctore Ecclesiae in Bethleem. In Stilting, Johannes et al. (eds). Acta Sanctorum Septembris [...], Tom. II, 418-688. Antverpiae. Toma Arhiđakon. 2003. Historia Salonitana. Povijest salonitanskih i splitskih prvosvećenika. Olga Perić, and Mirjana Matijević Sokol, ed. Split.

Verkholantsev, Julia. 2014. The Slavic Letters of St. Jerome: The History of the Legend and its Legacy, or, How the Translator of the Vulgate Became an Apostle of the Slavs. Dekalb IL.

Verkholantsev, Julia. 2010. Littera specialis... a beato Jeronimo: How Did Sts. Cyril and Methodius Lose Recognition as Inventors of the Glagolitic Letters to St. Jerome? In Ricerche slavistiche 54, 225-263.

Vetera monumenta Slavorum meridionalium. 1863. Vetera monumenta Slavorum meridionalium. Tomus primus: ab Innocento pp. usque ad Paulum PP. III (1198 - 1548). Augustino Theiner, ed. Romae.

Williams, Megan Hale. 2006. The Monk and the Book. Jerome and the Making of Christian Scholarship. Chicago and London.

Ivan Botica, $\mathrm{PhD}$.

Old Church Slavonic Institute

Demetrova 11

10000 Zagreb

Croatia

ibotica@stin.hr

Kristijan Kuhar, PhD.

Old Church Slavonic Institute

Demetrova 11

10000 Zagreb

Croatia

kristijan.kuhar@hotmail.com 